\title{
Difficulties in Translating Texts for Beginner Translator Students
}

\author{
Julia Eka Rini \\ English Department, Faculty of Letters, Petra Christian University \\ Surabaya, East Java, Indonesia \\ e-mail: jerini@peter.petra.ac.id
}

\begin{abstract}
Training students to transfer the message and meaning of the English source text to the Indonesian target text is not an easy task. Various difficulties and mistakes can occur. Students still have difficulties in understanding the text and in restructuring it into good Indonesian language. They still need to do a lot of exercises in transferring the meaning of the words, group of words or sentences.
\end{abstract}

Key words: message, meaning, difficulties, mistakes, transfer

In the English Department of Petra Christian University elective subjects are offered as certified professional packages of fourteen credits each and one of them is Translation Package (TP). Students can take the first course if they already pass Structure III, Reading III, and Writing III because students need to have adequate command of the language (English) first before they begin to translate. In the first course of these fourteen credits in TP, students are taught basic principles of translation. Students are trained to transfer meaning or message from the source text (ST), English, and to restructure it into the target text (TT), Indonesian. The materials used to train them are humor-of-situation texts of which language is not too difficult so that students can focus their attention in transferring the meaning or message or content of ST into TT.

Humor texts are used based on the following considerations. First, humor texts are expected to motivate students in doing translation because humor texts are funny. Second, this element of funniness can be used to test students' ability in transferring the content. If they or others can laugh when reading the translation, it means that their translation is already correct. If not, it means that there is a mistake in transferring the meaning.

It seems that transferring message or meaning and restructuring it into good Indonesian are not that easy. Students still make many mistakes in http://www.petra.ac.id/ puslit/journals/dir.php?DepartmentID $=I N G$ 
understanding the text and in restructuring it into good Indonesian. There are four stages in the translation process that can happen very fast or slow, only once or repeatedly, depending on the intensity of the difficulties encountered by the translators. The translation stages are analysis, transfer, restructuring and evaluation. In the stage of analysis, translators analyze the text to get the textual or contextual meaning of the text. In the stage of transfer, the meaning or message obtained from the analysis is transferred from the Source Text (ST) to the Target Text (TT). This stage happens in the translators' mind. In the stage of restructuring, translators write the TT, maintaining the equivalent content, meaning and message of the ST. The stage of evaluation and revision is where the translators evaluate the TT (the translation), whether or not it is the same as the ST. If it is not the same, then the TT is revised and the process is repeated from analysis. The diagram of translation process taken from Suryawinata (2003, p. 19) in Figure 1 summarizes the process of translation.

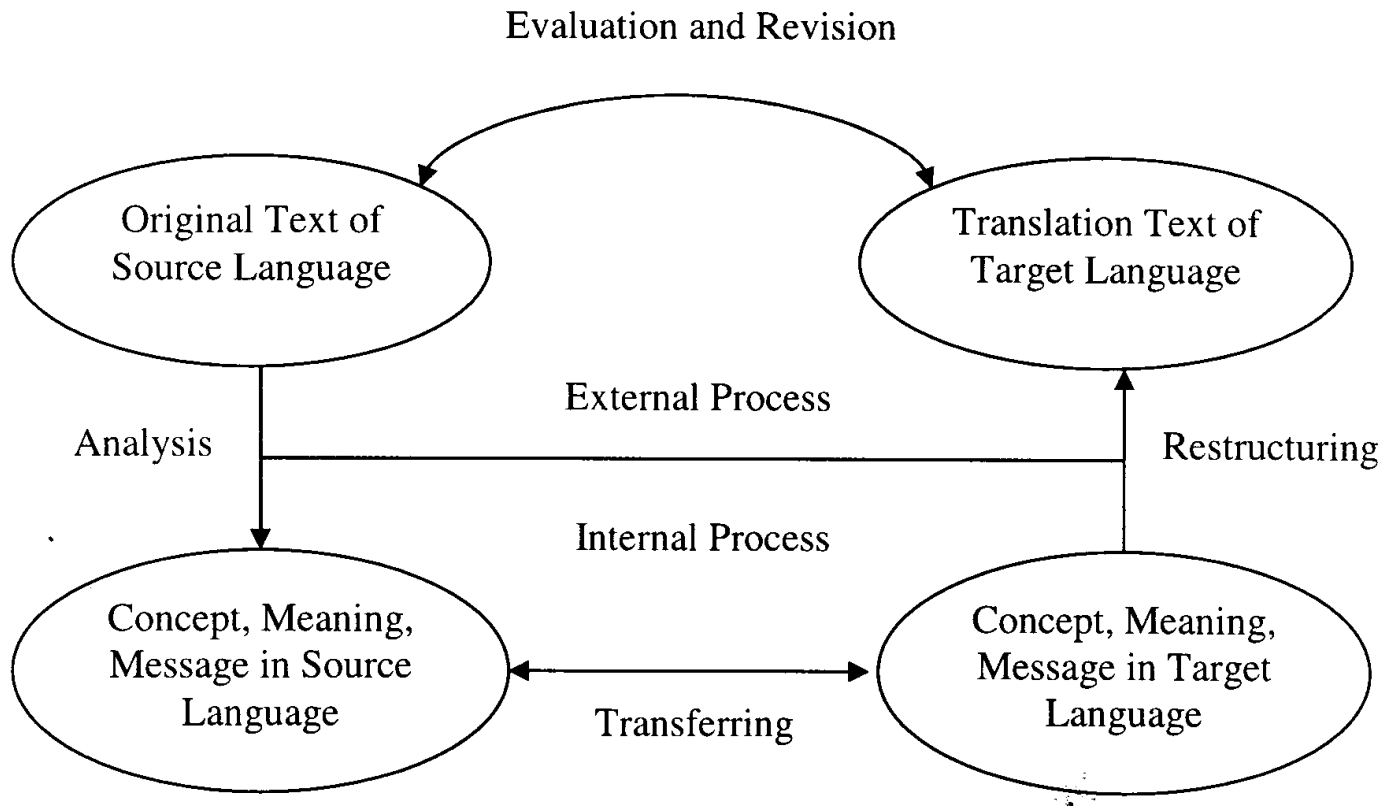

Figure 1. Translation Process

During the translation process, translators can pay attention to the whole text, one sentence, one clause, one group of words or even one word or referred to as translation unit (2004, p. 17). The unit of translation is the smallest segment of the utterance whose signs are linked in such a way that they should not be translated individually (2004, p. 138). A translator 
dealing with a short text as the example given by Hatim (2004, pp. 20-21) will divide up the ST below as follows:

Travelling from Heathrow

There are easy to follow instructions on the larger self-service touch screen ticket machines

[Travelling from Heathrow]

There are /

[easy to follow /instructions]/

[on the /larger /self-service/touch screen/ticket machines]

"The slashes (/) indicate small word groups with a distinct semantic meaning that might be considered separately, while the brackets ([...]) are larger units that a translator is likely to translate as a whole” (2004, p.21). About the unit of translation it is said further that

The unit of translation is normally the linguistic unit which the translator uses when translating. Translation theorists have proposed various units, from individual words and group to clause and sentence and even higher levels such as text and intertextual levels.... Importantly, Newmark (1988, pp. 66-67) makes the crucial point that 'all lengths of language can, at different moments and also simultaneously, be used as units of translation in the course of translation activity.' While it may be that a translator works at the sentence level, paying specific attention to problems raised by individual words or groups in that context, it is also important to take into account the function of the whole text and references to extra textual features. (2004, p. 25).

\section{METHODOLOGY}

There were twenty-four students taking translation I class and all of them should translate the following text into Indonesian.

(1) Mr. and Mrs. Williams had always spent their summer holidays in England in the past, in a small boarding house at the seaside. (2) One year, however, Mr. Williams made a lot of money in his business, so they decided to go to Rome and stay at a really good hotel while they went around and saw the sights of that famous city. (3) They flew to Rome, and arrived at their hotel late one evening. (4) They expected that they would have to go to bed hungry, because in the boarding 
house they had been used to in the past; no meals were served after seven o'clock in the evening. (5) They were therefore surprised when the clerk who received them in the hall of the hotel asked them whether they would be taking dinner there that night. (6) 'Are you still serving dinner then?' asked Mrs. Williams. (7) 'Yes, certainly, madam,' answered the clerk. (8) 'We serve it until half past nine.' (9) 'What are the times of meals then?' asked Mr. Williams. (10) 'Well, sir,' answered the clerk, 'we serve breakfast from seven to half past eleven in the morning, lunch from twelve to three in the afternoon, tea from four to five, and dinner from six to half past nine.' (11) 'But that hardly leaves any time for us to see the sights of Rome!' said Mrs. Williams in a disappointed voice. (Hill, 1965)

To make the analysis easy, the sentences in the text were numbered. There were eleven sentences and each sentence was divided into subjects, predicate, adverbs of manner, place, and time or units that had potentials for mistakes and was put into tables. Since there were twenty-four students' works that were analyzed, all students' translations were put in the Indonesian translation columns. If the translation was exactly the same, it was not written twice. Slight differences were shown using words in brackets or slashes. Some words were printed in bold to show where the mistake exactly is. Column of comments were filled with "wrong" if the translation produced by students was wrong. An example of the analysis is as follows:

\begin{tabular}{lll}
\hline English version & Indonesian translation & Comments \\
\hline They expected &... & -mereka menyangka \\
(sentence 4) & -mereka (sudah) mengira & \\
& -mereka berpikir & \\
& -mereka yakin & \\
& -mereka mengharapkan & Wrong \\
& -mereka berharap & Wrong \\
\hline
\end{tabular}

In this way it was easy to see the students' mistakes.

\section{FINDINGS AND DISCUSSION}

In the discussion of the difficulties in every sentence, each sentence was written before the discussion of the difficulties and was divided into translation units (it is shown by “”” to make the discussion easy). 
In translating the first sentence, "Mr. and Mrs. Williams /had always spent /their summer holidays/ in England /in the past/, in a small boarding house /at the seaside," students had several problems. First, "always" should be translated as selalu and not seringkali because the latter does mean that sometimes they do not do it. Second, to be precise, the plural form "holidays" can be expressed in setiap liburan musim panas mereka rather than repeating the word liburan because the word setiap in Indonesian is followed by a single noun; and it is certainly mereka and not nya, because nya is singular possessive pronoun. Some students still used "nya." Third, adverb of place "in England" should be translated di Inggris rather than di Negara Inggris, since the first already conveys that it is in the country (negara) of England; therefore it is not necessary to restate it. Fourth, "in the past" is good enough to be translated dahulu or dulu. Other translations such as di masa lampau, pada masa lalu, are not wrong, but they are not economical in terms of the length of words. Students still had difficulties in this matter. Fifth, a more precise translation of "in a small boarding house" is di sebuah rumah pondokan/pemondokan kecil rather than di sebuah penginapan(inn)/bungalow/hotel/losmen(inn) or rumah sewa/kontrakan(rented house)/vila/, because the latter does not indicate that a family is in the house while the definition of "a boarding house" is "a house in which people pay to live as guests with the family who owns it." Although it is not completely wrong because it is a place where people can stay, it becomes important to pay attention to because later on in the text, it is contrasted with "a really good hotel" when the Williams has become successful.

In translating the second sentence, "One year/, however/, Mr. Williams/made a lot of money/ in his business/, so they decided /to go to Rome/ and stay /at a really good hotel/ while they went around /and saw the sights of that famous city," students had difficulties in translating "one year." It can be seen in Table 1 that students attempted to transfer the meaning, but many students failed. A more general expression of time, like pada suatu ketika, suatu waktu/saat (one day) (the first three translations in Table 1) are more appropriate in Bahasa Indonesia, because the first three translations are also indefinite; like one year; the indefinite time must be transferred into Indonesian. 
Table 1. $2^{\text {nd }}$ Sentence

\begin{tabular}{|c|c|}
\hline English version & Indonesian translation \\
\hline One year, & $\begin{array}{l}\text { - pada suatu ketika } \\
\text { - suatu waktu } \\
\text { - suatu saat } \\
\text { - pada suatu tahun (not common in } \\
\text { Indonesian) } \\
\text { - pada satu tahun (not common in } \\
\text { Indonesian) } \\
\text { - } \text { setahun kemudian (one year later) } \\
\text { - selama satu tahun (during one year) } \\
\text { - } \text { satu tahun (not common in Indonesian) } \\
\text { - suatu tahun (not common in Indonesian) } \\
\text { - } \text { ada satu tahun (not common in } \\
\text { Indonesian) } \\
\text { - ada suatu tahun (not common in } \\
\text { Indonesian) } \\
\text { - tahun ini (this year) } \\
\text { - setelah setahun berselang (after one year) } \\
\text { - suatu saat dalam satu tahun (one moment } \\
\text { in one year) }\end{array}$ \\
\hline
\end{tabular}

Although "one day" can be translated as pada suatu hari, it does not mean that "one year" can be translated as pada suatu tahun. Other problems in the second sentence were probably not as difficult as the first one. The other translations were not correct, either it is because it is not common in Indonesian expression of time or the translation changes the indefinite time into definite (see other examples in Table 1).

In translating the third sentence, "They flew to Rome, / and arrived at their hotel/ late one evening/," students again had difficulties in translating the adverb of time as it can be seen in Table 2.

"Late one evening" can be translated into "(pada) larut malam or kemalaman or ketika hari sudah malam or malam sekali or terlambat malam itu. The others do not transfer the exact meaning, because evening is certainly not sore (afternoon) or petang (when it gets dark in the afternoon); in Indonesian "evening” is malam (after sore or petang). "Late one evening" is also indefinite because the exact time in the evening is not 
known; therefore terlambat sampai 1 jam di malam hari (one hour late in the evening) and pada tengah malam (midnight) is not appropriate, because in the original text this duration ( 1 hour) and the exact time (midnight) is not conveyed. Agak malam has the meaning of "not too late," while the original says "late one evening."

Table 2. $3^{\text {rd }}$ Sentence

\begin{tabular}{|c|c|}
\hline English version & Indonesian translation \\
\hline They flew to Rome, & $\begin{array}{l}\text { - mereka menelusuri Roma (they went } \\
\text { everywhere in Rome) } \\
\text { - mereka kembali ke Roma (they went } \\
\text { back to Rome) }\end{array}$ \\
\hline late one evening. & $\begin{array}{l}\text { - (pada) larut malam } \\
\text { - (agak)/(sudah) kemalaman } \\
\text { - ketika hari sudah malam } \\
\text { - malam sekali } \\
\text { - pada malam hari } \\
\text { - terlambat malam itu } \\
\text { - terlambat di suatu malam } \\
\text { - malam harinya } \\
\text { - agak malam (not too late) } \\
\text { - pada tengah malam (midnight) } \\
\text { - terlambat sampai } 1 \text { jam di malam } \\
\text { hari (one hour late in the evening) } \\
\text { - sore harinya (in the afternoon) } \\
\text { - pada petang harinya (in the } \\
\text { afternoon) } \\
\text { - pada waktu hari sudah gelap (when it } \\
\text { is dark) } \\
\text { - pada suatu sore, terlambat (late in the } \\
\text { afternoon) } \\
\text { - terlambat pada petang hari (late in } \\
\text { the afternoon) }\end{array}$ \\
\hline
\end{tabular}

Some students even made mistakes in translating the word "flew." Some students used the word menelusuri, which has the meaning that they are already in Rome and go everywhere in Rome, while "they flew to 
Rome” means that they are not yet in Rome, that they use an airplane to arrive in Rome. Kembali is going back to Rome; this is, of course, not the correct translation, since the meaning from the context is that it is their first visit.

In translating the fourth sentence, "They expected /that they would have to go to bed hungry, / because in the boarding-house /they had been used to in the past, / no meals were served /after seven o'clock/ in the evening, students had several difficulties.

First, "they expected" cannot be translated into mereka mengharapkan or mereka berharap, because these two translations have the meaning of "they hope," which is certainly not the meaning of "they expected." The right Indonesian translation is mengira/menyangka/berpikir, but not yakin because yakin is "convinced." which is stronger in the degree of certainty than "expected."

The second difficulty was the second translation unit. One student translated as pergi dengan kelaparan (go in the condition of being hungry), while the text is "to go to bed" which means "sleep" (tidur). While the translation dengan sambil menahan lapar, the students must choose dengan or sambil; s/he cannot use both. Mendapatkan makanan di tempat tidur (having some food in bed) and dapat langsung tidur dalam keadaan lapar (can directly go to sleep when they were hungry) are certainly not the meaning of the original text.

The third difficulty in translating this sentence is concerning the word "meals." It cannot be translated as camilan (snack) or daging (meat); it should be makanan (food) or makan malam (dinner). In this context makan malam can be used since "meals" refers to the one in the evening, although this word can refer to the meals any time in one day.

The case is different in the translation of the sentence "What are the times of meals then?" Some students translated it as jam berapa makan paginya (What time is breakfast). It is wrong because in this context meals do not refer to breakfast only, but also to lunch and dinner. The translation into apakah ada jam makan? (Is there any schedule for meals?) is certainly not correct because the English version does not ask whether or not meals are provided. It asks what times meals are provided.

In translating the fifth sentence, "They were therefore surprised/ when the clerk/ who received them in the hall of the hotel/asked them /whether they would be taking dinner/there/ that night, there was no serious mistake. One translation that needed revision was apakah mereka mau diantar 
untuk makan malam (whether they wanted to be accompanied to dinner or someone would take them to have dinner) as a translation for "whether they would be taking dinner." The focus of the question was not whether they wanted someone to accompany them to have dinner or not, but whether they would eat at the hotel or not. Some did not translate "there" and "that night"; while "clerk" is best translated as pegawai hotel or petugas hotel" or karyawan hotel and not pelayan hotel since they are receptionists; pelayan is helper. "In the hall of the hotel" is best translated as "lobi hotel"; some translated as di depan pintu(masuk) hotel (in front of the door of the hotel), di depan hotel (in front of the hotel) which are not correct.

Some students still had difficulties in translating the time, for example, "until half past nine," (sampai jam/pukul setengah sembilan), it should be sampai pukul setengah sepuluh, because setengah sembilan is 8.30. Also, "from seven to half past eleven in the morning" (dari jam tujuh pagi sampai jam setengah sebelas siang) should be setengah dua belas, because setengah sebelas is 10.30 . Some students also translated "in the morning" into pagi hari, which is not appropriate in Indonesian context; 11.30 is already siang hari in Indonesia.

In translating "But that hardly leaves any time for us to see the sights of Rome!” (sentence 11) some students made mistakes. The first mistake is translating the sentence into Tetapi itu sangatlah sulit bagi kami untuk meninggalkan waktu (But it is difficult for us to leave time); this certainly does not transfer the message. The other two-tetapi sangat berat bagi kami meninggalkan tempat ini (it is very hard for us to leave this place) and tapi ini akan membuat kami tidak rela (but this makes us not willing to...) - are not the meaning of the original either.

The other translation was about wrong reference in Bahasa Indonesia, because "we" in English can be translated into "kami" (referring only to the speakers) and "kita" (referring both to the speaker(s) and interlocutor(s). The correct translation of "we" in this context is kami, because "we" refers to the couple and not the couple and the clerk.

\section{CONCLUSION}

As it can be seen from the examples, students still make mistakes on trivial items, which are the problems of language. For beginners or translator trainees, it is not only transferring the content or meaning which 
needs to be paid attention to, but they still need to do a lot of exercises in the stage of analysis, in comprehending the source text and also in restructuring it into the target text.

\section{REFERENCES}

Hatim, B., \& Munday, J. (2004). Translation: An advanced resource book. London and New York: Routledge.

Hill, L. A. (1965). Advanced stories for reproduction. London: Oxford University Press.

Suryawinata, Z., \& Hariyanto, S. (2003). Translation: Bahasan teori \& penuntun praktis menerjemahkan. [Translation: Theoritical review \& practical guidance for translation]. Yogyakarta: Kanisius. 